\title{
RECYCLING OF HAZELNUT SHELL: SYNTHESIS OF BORON CARBIDE BY CARBOTHERMIC REACTION
}

\author{
Erhan Budak $^{1,2^{*}}$, Serdar Hizarci', Ercan Yilmaz ${ }^{2}$
}

${ }^{1}$ Department of Chemistry, Faculty of Art and Science, Bolu Abant Izzet Baysal University, Bolu, Turkey ${ }^{2}$ Center for Nuclear Radiation Detector Research and Applications, Bolu Abant Izzet Baysal University, Bolu, Turkey

\begin{abstract}
In the present study, boron carbide was prepared using boric acid and hazelnut shell activated carbon by a carbothermic reduction method at $1400^{\circ} \mathrm{C}$. Two different methods were applied to obtain activated carbon for this study; activated carbon production using hazelnut shells (I) and sulfuric acid treatment of hazelnut shells (II). The formation of boron carbide was proven by Fourier transformation infrared spectroscopy (FTIR) and X-ray diffraction(XRD), also the morphological examination was done by scanning electron microscopy (SEM). The average grain sizes were found as 30 and $7 \mathrm{~nm}$ for II and I, respectively. In addition, the calculated lattice parameters were closely matched with the reported values in the JCPDS card. It was found that hazelnut shells can be used as an alternative carbon source for boron carbide synthesis.
\end{abstract}

Keywords: Boron carbide, hazelnut shell, carbothermic reduction, activated carbon

\section{INTRODUCTION}

Boron carbide is a typical non-oxide advanced ceramic that used in different industrial applications due to its hardness, high refractoriness low density and good neutron absorption cross-section [1]. It is used in wear resistance applications, in lightweight armor plates [2], in the nuclear industry as neutron absorbers [3], and in the aerospace industry as a rocket propellant [4].

In general, boron carbide is produced by metallothermic or carbothermic processes. The metallothermic method is not favorable because of the high cost of reactant (elemental boron). The carbothermic process includes cheaper raw materials, for example, boron oxide and boric acid which is reduced by carbon to give boron carbide $[5,6]$. There are several studies for the usage of different types of carbon sources, such as citric acid gel [6-9], sucrose [10-13] and organic polymer precursor [14,15].

Hazelnut is one of the important agricultural products in Turkey. After hazelnut harvest, a small amount of the hazelnut shells is used as firewood in the countryside and a large portion of hazelnut shells remains as agricultural waste, so they cannot be evaluated for any significant purpose. Because of hazelnut shell contents (31\% hemicelluloses, 26\% cellulose, and 43\% lignin) [16] it could be an alternative carbon source.

The aims of this study were to synthesize boron carbide by carbothermic reduction reaction using hazelnut shells, exploring a possible usage of hazelnut shell as an alternative carbon source, and recycling the hazelnut shell agricultural waste.

\section{EXPERIMENTAL}

In the present study, firstly activated carbon was synthesized by two different methods: activated carbon production using hazelnut shells (Procedure I) and sulfuric acid treatment of hazelnut shells (Procedure II). For Procedure 1, the activated carbon was prepared according to Aygün [17]. In Procedure 2, the hazelnut shells were kept in concentrated sulfuric acid which is a common method for the carbonization of organic compounds for one week, and black residuals were filtered over glass wool and washed with hot distilled water to remove sulfate ions. Afterwards, carbonized hazelnut shells were dried in an oven at $100^{\circ} \mathrm{C}$. Then, boron carbide samples were prepared by the carbothermic reduction method. To do this, boric acid and hazelnut shell activated carbon were mixed with different ratio: 1:1, 1:2, 1:3, and 1:4, respectively. In addition, the main heating process was performed at $1000,1100,1200,1300$ and $1400^{\circ} \mathrm{C}$ under nitrogen and argon individually.However, the best result were obtained at $1400^{\circ} \mathrm{C}$ and given in the current study.

$1.0 \mathrm{~g}$ of boric acid and $0.25 \mathrm{~g}$ of activated carbon (obtained from Procedure I and II separately) were mixed and pressed under 10 atm for 15 minutes. After that, the pressed powder was heated at $1400^{\circ} \mathrm{C}$ (heating rate: $10^{\circ} / \mathrm{min}$ ) for three hours under argon (25 $\mathrm{mL} / \mathrm{min})$. The raw product was leached in $6 \mathrm{M} \mathrm{HCl}$ solution and dried in an oven at $100^{\circ} \mathrm{C}$.

*erhan@ibu.edu.tr 
Boron carbide stretching vibrations were determined by a Perkin Elmer Spectrum II FTIR-ATR spectrophotometer. XRD patterns were obtained by a Rigaku Multiflex diffractometer using $\mathrm{CuKa}$ radiation while micrographs were taken by FEI Quanta FEG 250 (the samples were coated with gold for 220 seconds at $4 \mathrm{~mA}$ by using Coxem KIC-1A ion-coater).

\section{RESULTS AND DisCUSSION}

Figure 1 illustrated the FTIR spectrum of hazelnut shells which is composed of cellulose, hemicelluloses, and lignin. There are several FTIR studies [18-20] in literature for characterizing hazelnut shell chemical bonds. The type of peaks and corresponding wavenumber were listed in Table 1.

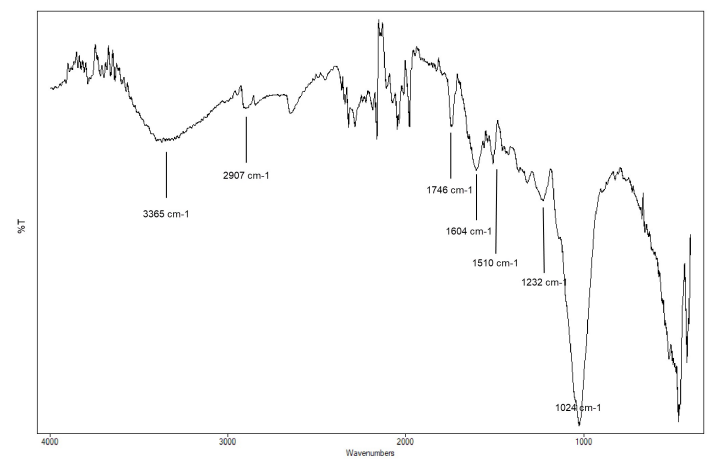

Figure 1. FTIR spectrum of hazelnut shell

Table 1. Wavenumber and assignments of hazelnut shells

\begin{tabular}{|c|c|}
\hline $\begin{array}{c}\text { Wavenumber } \\
\left(\mathrm{cm}^{-1}\right)\end{array}$ & Assignments \\
\hline 1027 & $\begin{array}{l}\mathrm{C}-\mathrm{C}, \mathrm{C}-\mathrm{H} \text { ring and side group } \\
\text { vibrations of aliphatic } \\
\text { hydrocarbons. }\end{array}$ \\
\hline 1232 & $\begin{array}{l}\mathrm{C}-\mathrm{OH} \text { bending of aliphatic } \\
\text { hydrocarbons. }\end{array}$ \\
\hline $1315-1420$ & $\begin{array}{l}\mathrm{C}-\mathrm{H} \text { bending vibrations of } \\
\text { aliphatic hydrocarbons. }\end{array}$ \\
\hline 1510 & $\begin{array}{l}\mathrm{C}=\mathrm{C} \text { stretching vibrations of the } \\
\text { lignocellulosic aromatic ring. }\end{array}$ \\
\hline 1604 & $\begin{array}{l}\mathrm{O}-\mathrm{H} \text { bending vibrations of } \\
\text { water. }\end{array}$ \\
\hline 1746 & $\begin{array}{l}\mathrm{C}=\mathrm{O} \text { stretching vibrations of } \\
\text { lignocellulosic carbonyl groups. }\end{array}$ \\
\hline 2907 & $\begin{array}{l}\mathrm{C}-\mathrm{H} \text { vibrations of aliphatic } \\
\text { hydrocarbons }\end{array}$ \\
\hline 3365 & $\begin{array}{l}\mathrm{O}-\mathrm{H} \text { stretching vibration of } \\
\text { water. }\end{array}$ \\
\hline
\end{tabular}

After sulfuric acid treatment of hazelnut shells (Procedure 2), nearly all groups of lignocellulosic compound vibrations disappeared in the FTIR spectrum (Figure 2a). However, aromatic $\mathrm{C}=\mathrm{C}$ and $\mathrm{C}-\mathrm{O}(\mathrm{C}=\mathrm{O})$ groups stretching in $\mathrm{G}$ rings (1569 and 1253 $\mathrm{cm}^{-1}$, respectively) were still observed [21-24]. In addition, a similar result (Figure 2b) was obtained in Procedure 1. Under this condition, the products can be considered as activated carbon.

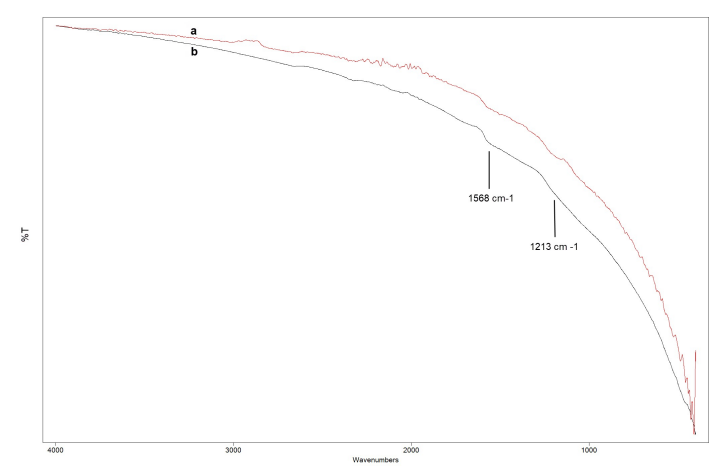

Figure 2. FTIR spectrum of activated carbons. a) Procedure 1, b) Procedure 2.

In the FTIR, spectra of boron carbide samples (figure 3) indicated the $\mathrm{B}-\mathrm{C}$ bond formation during the main heating process. The peak at $1190 \mathrm{~cm}^{-1}$ was labeled as the $\mathrm{B}-\mathrm{C}$ absorption band, while the peak at $1412 \mathrm{~cm}^{-1}$ was attributed to the $\mathrm{B}-\mathrm{O}$ stretching vibration [11,13,14]. The shifting $B$ - O stretching vibration to $1372 \mathrm{~cm}^{-1}$ (Figure $3 \mathrm{a}$ ) could be originated boron icosahedra [11].

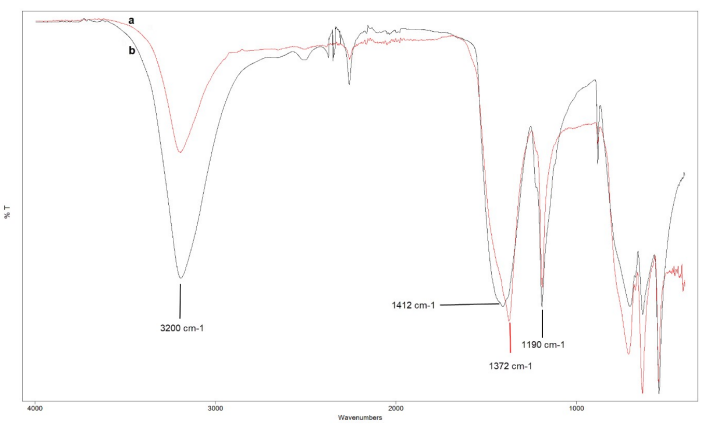

Figure 3. FTIR spectrum of boron carbides. a) Procedure 1, b) Procedure 2.

Figure 4 shows the XRD patterns of hazelnut shell activated carbon. Typical amorphous carbon diffraction peaks were detected at $2 \theta=25^{\circ}$ and $2 \theta=43^{\circ}$ in the XRD pattern. According to the XRD result, both hazelnut shell activated carbon contains graphite crystallite $[25,26]$.

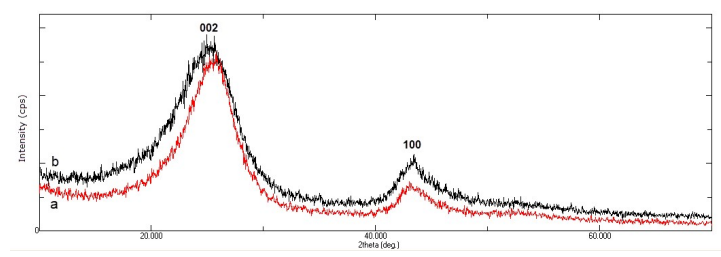

Figure 4. XRD pattern of activated carbons. a) Procedure 1, b) Procedure 2.

Also, the crystalline parameters of hazelnut activated carbon were calculated (Table 2) and these calculations showed that the interlayer distance of 
obtained activated carbons is higher than $3.35 \AA$ which indicates the formation of turbostratic (disordered) structures [27].

Table 2. Crystalline parameters of hazelnut activated carbon

\begin{tabular}{cccccc} 
Samples & $\mathbf{a}(\AA)$ & $\mathbf{c}(\AA)$ & $\begin{array}{c}\mathbf{d}_{\text {oon }} \\
(\AA)\end{array}$ & $\begin{array}{c}\mathbf{d}_{100} \\
(\AA)\end{array}$ & $\begin{array}{c}\text { Grain } \\
\text { Size } \\
(\mathbf{n m})\end{array}$ \\
\hline $\begin{array}{c}\text { Hazelnut } \\
\text { activated } \\
\text { carbon } \\
\mathrm{H}_{2} \mathrm{SO}_{4} \\
\text { treated } \\
\text { hazelnut } \\
\text { shell } \\
\text { carbon }\end{array}$ & 2.41 & 6.90 & 3.49 & 2.08 & 1.45 \\
\hline
\end{tabular}

$\mathrm{X}$-ray diffraction was applied for the determination of boron carbide crystallinity. In the present study, boron carbide signals were detected at $1400{ }^{\circ} \mathrm{C}$ by the carbothermic reduction reaction like previously studies $[7,28,29]$. The XRD result was compared to JCPDS card no. 35-0798 and characteristic XRD peaks of boron carbide were observed (Figure 5). However, the XRD pattern of products indicated the presence of graphite and boron oxide, too. According to the studies $[10,11]$, the boron oxide and graphite were always observed below $1600{ }^{\circ} \mathrm{C}$ when organic precursors were used.

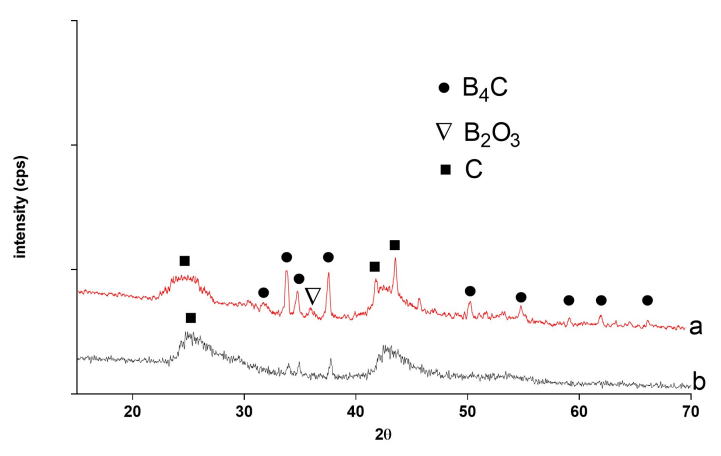

Figure 5. XRD pattern of boron carbides. a) Procedure 1, b) Procedure 2.

It was observed that the usage of hazelnut activated carbon provided better results than sulfuric-acidtreated activated carbon in the XRD pattern. This may be probably originated by a degree of graphitization. Small doo2 value (Table 2) was the indication of a high degree of graphitization and increased reaction activity of activated carbon [26]. Also, using the Scherrer equation average grain size of boron carbides was calculated as $30 \mathrm{~nm}$ (Procedure 1) and $7 \mathrm{~nm}$ (Procedure 2) and other calculated parameters were given in Table 3. The parameters were closely matched with the reported values in JCPDS card no. 35-0798.

Table 3. Crystalline parameters of boron carbide samples

\begin{tabular}{cccc} 
Samples & $\mathbf{a}(\mathbf{\AA})$ & $\mathbf{c}(\AA)$ & $\begin{array}{c}\text { Grain Size } \\
(\mathbf{n m})\end{array}$ \\
\hline Procedure 1 & 5.60 & 12.13 & 30 \\
Procedure 2 & 5.62 & 12.14 & 7 \\
\hline
\end{tabular}

Different micrographs of boron carbide samples were obtained (Figure 6) in SEM analysis. In Figure 6a, nearly equiaxed particles (Procedure 1) were observed, whereas a conglomerated honeycomb with pores surrounded by carbons (Procedure 2) was detected in Figure $6 \mathrm{~b}$.
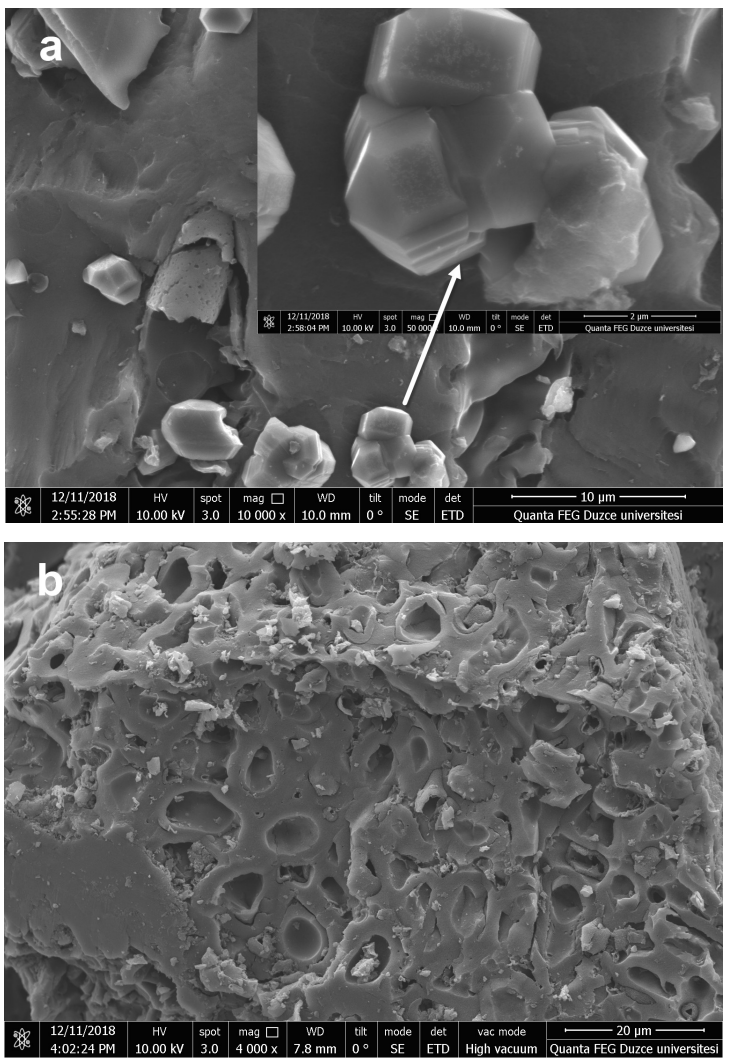

Figure 6. SEM images of boron carbides. a) Procedure 1, b) Procedure 2.

\section{CONCLUSION}

In summary, boron carbide samples were prepared by the carbothermal reaction of boric acid and hazelnut shells composed of cellulose, hemicelluloses, and lignin. These groups were converted to aromatic $\mathrm{C}=\mathrm{C}$ and $\mathrm{C}=\mathrm{O}$ group during the active carbon formation and reduced boric acid to elemental boron. As a result, boron carbide was formed at relatively low temperature by the reaction of elemental boron and carbon. Usage of $1 \mathrm{~g}$ boric acid and $0.25 \mathrm{~g}$ activated carbon was found as ideal mixture among the study. XRD results confirmed that boron carbide formation and the average grain size of boron carbides was computed as $30 \mathrm{~nm}$ (Procedure 1) and $7 \mathrm{~nm}$ (Procedure 2). These results showed that hazelnut shell can be used as an alternative carbon source for synthesis of boron carbide.

Acknowledgements: This work is supported by the Presidency of Turkey, Presidency of Strategy and Budget under Contract Number: 2016K121110. 
REFERENCES

1. F. Thévenot, "Boron carbide-A comprehensive review," J. Eur. Ceram. Soc., vol. 6, no. 4, pp. $205-$ 225, 1990. DOI: 10.1016/0955-2219(90)90048-K

2. K. A. Schwetz, L. S. Sigl, L. Pfau, "Mechanical Properties of Injection Molded B4C-C Ceramics," J. Solid State Chem., vol. 103, no. 1, pp. $68-76$, Oct. 1997. DOI: $10.1006 /$ jssc.1997.7316

3. D. K. Bose, K. U. Nair, C. K. Gupta, "Production of High Purity Boron Carbide," High Temp. Mater. Process., vol. 7, no. 2 - 3, pp. 133 - 140, 1986.

DOI: 10.1515/HTMP.1986.7.2-3.133

4. C. F. Bilsby, A. M. T. Bell, F. W. Morris, "Swelling of boron carbide under fast neutron irradiation," in EMAG-MICRO 89, vol. 1, P. J. Goodhew, H. Y. Elder, Eds., Bristol, UK: Institute of Physics, 1990.

Retrieved from:

http://inis.iaea.org/search/search.aspx?orig q $\mathrm{q}$ R

$\mathrm{N}: 23057613$

Retrieved on: Apr. 11, 2019

5. A. Alizadeh, E. Taheri-Nassaj, N. Ehsani, "Synthesis of boron carbide powder by a carbothermic reduction method," J. Eur. Ceram. Soc., vol. 24, no. $10-11$, pp. $3227-3234$, Sep. 2004.

DOI: 10.1016/j.jeurceramsoc.2003.11.012

6. Dj. Kosanović, Lj. Milovanović, S. Milovanović, A. Šaponjić, "Low-Temperature Synthetic Route for Boron Carbide Powder from Boric Acid-Citric Acid Gel Precursor," Mater. Sci. Forum., vol. 555, pp. $255-260$, Sep. 2007.

DOI: 10.4028/www.scientific.net/msf.555.255

7. A. Sinha, T. Mahata, B. P. Sharma, "Carbothermal route for preparation of boron carbide powder from boric acid-citric acid gel precursor," J. Nucl. Mater., vol. 301, no. 2 - 3, pp. 165 - 169, Mar. 2002.

DOI: $10.1016 /$ SoO22-3115(02)00704-3

8. A. M. Hadian, J. A. Bigdeloo, "The effect of time, temperature and composition on boron carbide synthesis by sol-gel method," J. Mater. Eng. Perform., vol. 17, no. 1, pp. 44 - 49, Feb. 2008. DOI: $10.1007 / \mathrm{s} 11665-007-9125-0$

9. A. K. Khanra, "Production of boron carbide powder by carbothermal synthesis of gel material," Bull. Mater. Sci., vol. 30, no. 2, pp. 93 - 96, Apr. 2007. DOI: $10.1007 / \mathrm{s} 12034-007-0016-7$

10. T. R. Pilladi, K. Ananthansivan, S. Anthonysamy, "Synthesis of boron carbide from boric oxidesucrose gel precursor," Powder Technol., vol. 246, pp. $247-251$, Sep. 2013. DOI: 10.1016/j.powtec.2013.04.055

11. E. Çakır, C. Ergun, F. Ç. Şahin, İ. Erden, "In Situ Synthesis of B4C / TiB2 Composites from Low Cost Sugar Based Precursor," Defect Diffus. Forum, vol. $297-301$, pp. $52-56$, Apr. 2010. DOI: 10.4028/www.scientific.net/DDF.297-301.52

12. H. Konno, A. Sudoh, Y. Aoki, H. Habazaki, "Synthesis of C/B 4 C composites from sugar-boric acid mixed solutions," Mol. Cryst. Liq. Cryst., vol. 386 , no. 1, pp. 15 - 20, 2002. DOI: $10.1080 / 713738826$

13. M. G. Rodríguez, O. V. Kharissova, U. OrtizMéndez, "Formation of boron carbide nanofibers and nanobelts from heated by microwave," Rev. Adv. Mater. Sci., vol. 7, no. 1, pp. 55 - 6o, Jul. 2004.

Retrieved from: http://www.ipme.nw.ru/ejournals/RAMS/no_1704/rodriguez/rodriguez.pdf Retrieved on: Jun. 18, 2019

14. S. Mondal, A. K. Banthia, "Low-temperature synthetic route for boron carbide," J. Eur. Ceram. Soc., vol. 25, no. 2 - 3, pp. 287 - 291, Dec. 2005.
DOI: 10.1016/j.jeurceramsoc.2004.08.011

15. M. Antadze et al., "Metal-ceramics based on nanostructured boron carbide," Solid State Sci., vol. 14, no. 11 - 12, pp. 1725 - 1728, Nov. 2012. DOI: 10.1016/j.solidstatesciences.2012.08.004

16. A. Demirbas, "Relationships between lignin contents and fixed carbon contents of biomass samples," Energy Convers. Manag., vol. 44, no. 9, pp. $1481-1486$, Jun. 2003. DOI: 10.1016/So196-8904(02)oo168-1

17. A. Aygün, S. Yenisoy-Karakas, I. Duman, "Production of granular activated carbon from fruit stones and nutshells and evaluation of their physical, chemical and adsorption properties," Microporous Mesoporous Mater., vol. 66, no. 2 - 3, pp. $189-195$, Dec. 2003. DOI: 10.1016/j.micromeso.2003.08.028

18. H. Uzun, E. G. Kaynak, E. Ibanoglu, S. Ibanoglu, "Chemical and structural variations in hazelnut and soybean oils after ozone treatments," Grasas y Aceites, vol. 69, no. 2, Jun. 2018

DOI: $10.3989 /$ gya.1098171

19. S. Li, X. Chen, A. Liu, L. Wang, G. Yu, "Co-pyrolysis characteristic of biomass and bituminous coal," Bioresour. Technol., vol. 179, pp. $414-420$, Mar. 2015.

DOI: 10.1016/j.biortech.2014.12.025

20. A. O. Odeh, "Oualitative and quantitative ATRFTIR analysis and its application to coal char of different ranks," J. Fuel Chem. Technol., vol. 43, no. 2, pp. 129 - 137, Feb. 2015.

DOI: 10.1016/s1872-5813(15)30001-3

21. E. Aracri, C. D. Blanco, T. Tzanov, "An enzymatic approach to develop a lignin-based adhesive for wool floor coverings," Green Chem., vol. 6, no. 5, Feb. 2014. DOI: $10.1039 / \mathrm{c} 4 \mathrm{gco0063c}$

22. E. Pehlivan, "Production and Characterization of Activated Carbon From Pomegranate Pulp by Phosphoric Acid," J. Turk. Chem. Soc. Sect. A: Chem., vol. 5, no. 2, pp. $1-8,2018$. DOI: $10.18596 /$ jotcsa. 370738

23. J. Shu et al., "Copper loaded on activated carbon as an efficient adsorbent for removal of methylene blue," RSC Adv., vol. 7, no. 24, pp. 14395 - 14405 Mar. 2017. DOI: $10.1039 / \mathrm{c} 7 \mathrm{ra00287d}$

24. I. A. W. Tan, M. O. Abdullah, L. L. P. Lim, T. H. C. Yeo, "Surface Modification and Characterization of Coconut Shell-Based Activated Carbon Subjected to Acidic and Alkaline Treatments," J. Appl. Sci. Process Eng., vol. 4, no. 2, pp. 186 - 194, 2017. DOI: $10.33736 /$ jaspe.435.2017

25. S. Wang, G. Q. Lu, "Effects of Oxide Promoters on Metal Dispersion and Metal-Support Interactions in Ni Catalysts Supported on Activated Carbon," Ind. Eng. Chem. Res., vol. 36, no. 12, pp. 5103 5109, Dec. 1997. DOI: 10.1021/ie9703604

26. Z. Xie, W. Guan, F. Ji, Z. Song, Y. Zhao, "Production of Biologically Activated Carbon from Orange Peel and Landfill Leachate Subsequent Treatment Technology," J. Chem., vol. 2014, Jun. 2014. DOI: $10.1155 / 2014 / 491912$

27. B. S. Girgis, Y. M. Temerk, M. M. Gadelrab, I. D. Abdullah, "X-ray Diffraction Patterns of Activated Carbons Prepared under Various Conditions," Carbon Lett., vol. 8, no. 2, pp. 95 100, Jun. 2012. DOI: $10.5714 / \mathrm{cl} .2007 .8 .2 .095$

28. T. K. Roy, C. Subramanian, A. K. Suri, "Pressureless sintering of boron carbide," Ceram. Int., vol. 32, no. 3, pp. 227 - 233, Dec. 2006. DOI: $10.1016 /$ j.ceramint.2005.02.008 
E. Budak et al., Recycling of hazelnut shell..., RAP Conf. Proc., vol. 4, 2019, 162-166

29. R. K. Dash, A. Nikitin, Y. Gogotsi, "Microporous carbon derived from boron carbide," Microporous Mesoporous Mater., vol. 72, no. 1 - 3, pp. 203 208, Jul. 2004.

DOI: 10.1016/j.micromeso.2004.05.001 